\title{
Peran Elkana dan Hana Terhadap Masa Kecil Samuel: Tahap Awal Mencetak Pemimpin Kristen
}

\author{
Wisnu Prabowo \\ Mahasiswa Pascasarjana Sekolah Tinggi Teologi Berita Hidup \\ Email:wisnupra@gmail.com
}

\begin{abstract}
Christian leadership is an important thing that must be prepared properly. Christian values must be a value that differentiates them from other leadership values. A Christian leader is not just an ordinary leadership role. Christian leaders must also be able to prepare a leadership successor. In the leadership of Imam Eli, Samuel was the successor to the leadership chosen by God. Samuel was a stranger to Imam Eli, but God prepared Samuel to be the successor of Imam Eli's leadership. This study is a qualitative study using the literature study method. This study examines the attitudes and roles of Elkanah and Hannah as parents in Samuel's childhood life. The results obtained are: First, parents who are obedient and loyal to God have an important role in the early stages of forming a Christian leader. Second, parents must take care and must prepare each child properly in order to be able to serve God and to become a Christian leader. After caring for and preparing a child, parents must also give consent for their child to serve God. Christian leadership is not formed in an instant way, but is formed when prospective Christian leaders are young.
\end{abstract}

Keywords: Leadership, Christianity, Parents, Children

\begin{abstract}
Abstrak
Kepemimpinan Kristen adalah hal penting yang harus dipersiapkan dengan baik. Nilai-nilai kekristenan harus menjadi nilai yang membedakan dengan nilai kepemimpinan yang lainnya. Seorang pemimpin kristen bukan hanya sekedar menjalankan peran kepemimpinan yang biasa saja. Pemimpin kristen juga harus mampu menyiapkan seorang penerus kepemimpinan. Di dalam kepemimpinan Imam Eli, Samuel adalah penerus kepemimpinan yang dipilih Tuhan. Samuel adalah orang asing bagi Imam Eli, tetapi Tuhan menyiapkan Samuel untukbisa menjadi penerus kepemimpinan Imam Eli. Kajian ini merupakan penelitian kualitatif yang menggunakan metode studi pustaka. Kajian ini meneliti sikap dan peran Elkana dan Hana sebagai orang tua di dalam kehidupan masa kanak-kanak Samuel. Hasil kajian yang diperoleh adalah: Pertama, orang tua yang taat dan setia kepada Tuhan mempunyai peran penting di dalam tahap awal pembentukan seorang pemimpin kristen. Kedua, orang tua harus merawat dan harus mempersiapkan setiap anaknya dengan baik dengan tujuan untuk bisa melayani Tuhan dan untuk menjadi seorang pemimpin kristen. Setelah merawat dan mempersiapkan seorang anak, orang tua juga harus memberi
\end{abstract}


persetujuan kepada anaknya untuk bisa melayani Tuhan. Kepemimpinan kristen tidak dibentuk dengan cara instant, tetapi dibentuk sejak calon pemimpin kristen berusia kanakkanak.

Kata kunci : Kepemimpinan, Kristen, Orang Tua, Anak

\section{Pendahuluan}

Pemilihan penerus kepemimpinan di dalam kehidupan sebuah organisasi sangatlah penting. Diperlukan seorang pemimpin untuk bisa membangkitkan seorang pemimpin yang baru (John C. Maxwell, 1999) melalui proses regenerasi kepemimpinan di dalam sebuah organisasi. Hal ini juga terjadi di dalam sebuah organisasi kekristenan, terutama di bidang pelayanan, baik itu di gereja maupun di organisasi kristen lainnya. Regenerasi pemimpin menjadi isu yang sangat penting untuk dibicarakan dan dilakukan. Walaupun menjadi sebuah isu yang sangat penting, akan tetapi isu regenerasi pemimpin baru dalam sebuah organisasi kristen mempunyai pergumulan dan masalah tersendiri dibandingkan dengan organisasi non kristen. Dimana terdapat beberapa standar ataupun syarat yang menjadi sebuah hal penting untuk dijadikan sebagai acuan di dalam pemilihan penerus kepemimpinan di organisasi kristen.

Profil dan kemampuan dari para calon pemimpin mempunyai mempunyai peran penting di dalam pemilihan regenerasi kepemimpinan, baik itu secara kemampuan akademik maupun nonakademik. Tetapi tidak menjadi kalah penting adalah peran dan kemampuan dari pemimpin yang mempersiapkan regenerasi tersebut. Bisa dikatakan kedua belah pihak, baik calon pemimpin maupun pemimpin itu sendiri saling berkaitan untuk bisa menghasilkan regenerasi kepemimpinan yang baik.

Tidak dapat dipungkiri bahwa kehidupan masa sekarang menjadikan tidak mudah untuk mencari penerus kepemimpinan yang baik. Dimana tekanan keuangan, komunitas maupun keinginan untuk aktualisasi diri menjadikan masingmasing orang mempunyai keinginan untuk menjadi lebih baik di dalam kehidupannya. Hal tersebut seringkali ditempuh melalui proses yang dipercepat, tanpa melalui proses yang menjadi bekal dalam menjalankan fungsi kepemimpinan. Sehingga dapat dengan mudah ditemukan sosok seorang pemimpin yang tidak menjalankan fungsi kepemimpinannya dengan baik.

Masing-masing organisasi kristen mempunyai standar sendiri untuk menentukan syarat sebagai pemimpin. Penulis melihat ada gereja, sinode maupun 
sekolah kristen yang sedemikian ketat memilih orang-orang sebagai pemimpin. Bahkan seringkali sangat sulit untuk mendapatkan calon pemimpin yang sesuai dengan standar yang dimiliki (MacArthur, 2004, p. 3). Bahkan karena standar yang sangat ketat, menjadikan para calon pemimpin kesulitan untuk memenuhi kualifikasi yang diperlukan.

Permasalahan standart sebagai pemimpin yang sangat ketat, membuat organisasi kristen sulit untuk menemukan penerus di dalam kepemimpinan. Tidak adanya fungsi mentoring atau pembapaan di dalam sebuah organisasi kristen menjadikan permasalahan ini semakin rumit. Bahkan ada dinamika pergantian atau regenerasi kepemimpinan disertai dengan perebutan kekuasaan, masingmasing orang menganggap dirinya sendiri layak menjadi pemimpin dan kemudian mencari dukungan dari orang lain untuk menjadikan dirinya sebagai pemimpin. Masing-masing orang menganggap dirinya lebih pantas menjadi pemimpin dibandingkan oleh orang lain.

Ketika salah satu pihak atau salah satu orang kalah di dalam hal perebutan menjadi penerus sebuah kepemimpinan, maka akan terjadi sebuah kubu. Kubu tersebut adalah kubu yang menunggu masa pemilihan regenerasi berikutnya untuk bisa menang. Bahkan terjadi pula, karena perebutan kekuasaan sebagai pemimpin, organisasi kristen menjadi terpecah. Ada pihak yang menang dan ada pihak yang kalah. Ada pihak yang tinggal tetap, ada pihak yang pergi. Pemilihan regenerasi kepemimpinan atau pencarian penerus kepemimpinan malah menjadi sarana perpecahan organisasi.

Sangat terlihat bahwa regenerasi kepemimpinan menjadi sesuatu hal yang penting. Hal yang penting ini sudah menjadi sebuah prioritas dari seorang pemimpin. Seorang pemimpin bisa melakukan pembapaan atau mentoring di dalam agenda kesehariannya sebagai seorang pemimpin. Seorang pemimpin tidaklah hanya sekedar mencari pemimpin baru untuk meneruskan kepemimpinannya, tetapi seorang pemimpin seharusnya mencetak pemimpin yang pada saatnya nanti akan menjadi penerus di dalam regenerasi kepemimpinannya. Di tahapan inilah sebuah proses pembapaan dari seorang pemimpin kepada para calon pemimpin menjadi sangat penting.

Sebagai organisasi Kristen, sudah seharusnya pola dari pembapaan atau mentoring yang dilakukan adalah berdasarkan nilai-nilai dari Alkitab. Suatu pola yang mengikuti hikmat Tuhan, tidak mengikuti hikmat dan kualifikasi dari dunia. Di dalam Alkitab, ada sebuah pola pembapaan yang menghasilkan seorang pemimpin yang dipakai Tuhan, yaitu 
Samuel. Samuel akan menjadi seorang pemimpin Israel. Samuel dipersiapkan untuk menjadi seorang imam bagi Israel, yang bukan hanya sebagai seorang hakim, tetapi juga sebagai seorang nabi bagi Israel (Bakker, 1993, p. 749). Proses yang di alami oleh Samuel untuk menuju sebagai seorang pemimpin sangat perlu dipelajari. Sehingga diharapkan dengan mempelajari proses pembapaan yang dialami oleh Samuel dapat diperoleh petunjuk tentang bagaimana cara melakukan proses pembapaan di dalam mempersiapkan calon pemimpin kristen yang baik.

Artikel ini secara khusus meneliti peran dari seorang Elkana dan Hana sebagai orang tua dari Samuel. Peran dari Elkana dan Hana yang ditulis di dalam firman Tuhan 1 Samuel 1-2 (Indonesia, 2005, pp. 1 Samuel 1-2). Bagian firman Tuhan ini terdapat di bagian awal Kitab 1 dan 2 Samuel, yang di dalam bagian awal ini terdapat informasi tentang masa hidup Samuel ketika masih berusia anak-anak. Masa kanak-kanak Samuel sangatlah menarik untuk diteliti dan dipelajari, karena ternyata sejak kanak-kanak inilah Samuel mulai dibentuk untuk menjadi seorang pemimpin. Perlu diteliti apa saja peran dari Elkana dan Hana kepada Samuel? Kenapa Elkana dengan mudahnya meninggalkan Samuel yang masih kecil di Silo? Bagaimana Samuel bisa menjadi pelayan Tuhan sejak masih kanak-kanak?

\section{Metode Penelitian}

Artikel ini meneliti hal-hal, peristiwa-peristiwa ataupun keadaan yang berkaitan dengan peran Elkana dan Hana kepada Samuel di masa Samuel masih berusia kanak-kanak melalui metode penelitian daftar pustaka, yaitu mencari dan mengumpulkan data-data pustaka (Hamzah, 2020, p. 24) yang berkaitan dengan proses mentoring dan teladan yang ada di dalam 1 Samuel1-2. Juga meneliti apa saja yang dilakukan oleh imam Eli kepada Samuel di masa Samuel berusia kanak-kanak sehingga mengawali pembentukan regenerasi kepemimpinan di jaman imam Eli, kemudian ditarik kesimpulan berdasarkan data atau fakta yang ditemukan.

Artikel ini ditulis dengan melakukan penelitian melalui metode studi pustaka, sehingga bisa diketahui apa yang terjadi di masa Samuel berusia anakanak yang menyebabkan dimulainya proses pembentukan Samuel sebagai pemimpin dan pelayan Tuhan.

\section{Jabatan Imam Di Jaman Abraham Hingga Eli}

\section{Kitab Pentateukh}

Untuk mempelajari kepemimpinan di masa Samuel melayani di Israel, perlu 
dipelajari apa yang terjadi di dalam masamasa sebelum Samuel melayani. Masamasa dimana seorang pemimpin dipilih di tengah-tengah rakyat Israel untuk memimpin Israel. Kitab Pentateukh, yang ditulis oleh Musa (LaSor et al., 2016, p. 102), menuliskan beberapa hal tentang kepemimpinan yang berada di dalam jabatan imam. Dimulai dari zaman Abraham mulai dikenalkan dengan istilah imam di dalam diri Melkisedek (Kejadian 14:18). Melkisedek sebagai imam Allah Yang Mahatinggi memberkati Abraham dan menerima persembahan persepuluhan dari Abraham. Melkisedek adalah raja negeri Salem yang menyembah Allah. Tidak seperti kebanyakan raja di masa itu yang tidak menyembah Allah, Melkisedek menyembah Allah yang sama seperti Abraham (Kejadian 14:22).

Penyebutan imam di Pentateukh berlanjut saat petunjuk pembuatan Kemah suci diberikan Tuhan kepada Musa. Jabatan imam, oleh Tuhan secara langsung diberikan kepada Harun dan anak-anaknya di Keluaran 28:1, "Engkau harus menyuruh abangmu Harun bersamasama dengan anak-anaknya datang kepadamu, dari tengah-tengah orang Israel, untuk memegang jabatan imam bagi-Ku--Harun dan anak-anak Harun, yakni Nadab, Abihu, Eleazar dan Itamar"(Indonesia, 2005, p. Keluaran 28:1). Walaupun Nadab dan Abihu mati karena mereka melakukan dosa (Imamat 10), tetapi jabatan imam tetap dipegang dan diteruskan oleh keturunan Harun yaitu Eleazar dan Itamar. Terlihat jelas di Bilangan 3:10, bahwa hanya Harun dan anak-anaknya yang diperbolehkan Tuhan untuk memegang jabatan imam. Sesuai firman Tuhan di dalam Bilangan 3:6, imam Harun dilayani oleh suku Lewi. Bisa dilihat bahwa sejak awal keberadaannya, bahwa jabatan imam adalah tugas yang khusus dan penting. Sebuah tugas yang secara langsung diberikan oleh Tuhan kepada orang-orang yang dipilihnya.

Imam dipilih Tuhan dengan sebuah tugas pekerjaan yang juga sudah ditentukan oleh Tuhan. Jabatan imam mempunyai tugas menjadi perantara antara Allah dan umat-Nya. Imam juga mempunyai tugas untuk mempersembahkan korban kepada Allah, berdoa untuk rakyat Israel dan juga sesuai dengan Bilangan 6:24-26 para imam juga memberkati rakyat Israel atas nama Allah.

Jabatan imam bagi Israel yang diemban oleh Harun dilanjutkan oleh anaknya. Saat Harun mati, saat itu juga Tuhan berfirman kepada Musa untuk mengenakan pakaian jabatan imam yang dilepaskan oleh Harun kepada Eleazar, Bilangan 20:22-28. 


\section{Kitab Yosua}

Saat orang Israel memasuki Kanaan, Musa sekali lagi mengajarkan undang-undang Allah dengan baik dan terang. Hal ini dilakukan oleh Musa karena orang Israel yang akan memasuki tanah Kanaan adalah para angkatan baru. Sehingga Musa menyuruh mereka untuk memelihara segala perintah dan aturan dari Allah dengan baik, supaya mereka tidak terkena hukuman dari Allah.

Saat Allah menyuruh Musa untuk mendaki ke gunung Nebo, ditunjukkanlah kepada Musa negeri yang dijanjikan Allah kepada Israel. Lalu Musa mati di tanah Moab.Yosua bin Nun, yang telah diberkati oleh Tuhan melalui Musa menggantikan Musa sebagai pemimpin orang Israel, Ulangan 34:9. Saat Musa mati dan digantikan oleh Yosua, jabatan imam tetap dipegang oleh Eleazar.

Sebelum Eleazar mati, Pinehas, anak Eleazar, juga sudah diangkat menjadi imam. Sehingga saat Eleazar mati, Pinehas langsung meneruskan jabatan imam yang dimiliki oleh Eleazar, Yosua 24:33 (Bakker, 1993, p. 422). Sesuai janji Allah kepada Pinehas yang disampaikanNya kepada Musa bahwa jabatan keimaman selama-lamanya bagi Pinehas dan keturunannya, Bilangan 25:10-13.

\section{Kitab Hakim-hakim}

Setelah Yosua mati, mulailah bangsa Israel berperang menyerang bangsa Kanaan dengan suku Yehuda lah yang maju pertama kali. Setelah itu sukusuku Israel menyusul untuk menyerang daerah-daerah Kanaan yang lain. Akan tetapi setelah Yosua mati, orang Israel melakukan yang jahat di mata Tuhan. Mereka meninggalkan Tuhan. Sehingga Tuhan murka dan menyerahkan orang Israel kepada para perampok dan mendatangkan malapetaka bagi orang Israel.

Akan tetapi, saat para orang Israel sudah sangat terdesak, Tuhan membangkitkan hakim-hakim yang menyelamatkan mereka dari tangan perampok itu. Setiap kali Tuhan membangkitkan seorang hakim untuk bangsa Israel, maka Tuhan menyertainya dan menyelamatkan bangsa Israel dari tangan musuh. Tetapi setelah hakim itu mati, bangsa Israel kembali melakukan hal yang jahat. Peristiwa itu selalu berulang di masa Hakim-hakim ini. Seorang pemimpin yang menyelamatkan bangsa Israel Tuhan sendiri yang memilih dan mengangkatnya.

Tuhan berturut-turut mengangkat Otniel, Ehud, Samgar, Debora dan Barak, Gideon. Gideon menjadi contoh bahwa seorang hakim yang dipilih Tuhan pun masih tergoda untuk melakukan dosa. Gideon hendak dijadikan raja oleh orang Israel sebagai ucapan terima kasih atas peran Gideon mengalahkan orang Midian. 
Gideon menolak hal tersebut, tetapi Gideon hidup seperti seorang raja. Gideon mempunyai banyak istri sehingga anak laki-lakinya berjumlah tujuh puluh orang. Salah satu gundiknya yang tinggal di Sikhem melahirkan seorang anak laki-laki bagi Gideon dan diberikan nama Abimelekh. Gideon juga meminta sebagian dari hasil jarahan orang Israel yang berupa cincin emas dan perhiasan lainnya. Emas itu digunakan Gideon untuk membuat efod, yaitu pakaian kebesaran imam. Gideon hendak mengadakan agamanya sendiri, dengan demikian orang Israel datang kepadanya dan tidak lagi datang ke Silo dimana rumah Allah ada disana, Hakim-hakim 18:31.

Gideon mati setelah empat puluh tahun menjadi hakim bagi orang Israel. Lalu Abimelekh mengajukan diri menjadi raja bangsa Israel. Abimelekh menjadi raja tanpa restu dari Tuhan. yang mengangkat Abimelekh menjadi raja adalah orangorang penduduk Sikhem. Setelah tiga tahun masa raja Abimelekh memerintah atas orang Israel, Tuhan membangkitkan hakim-hakim yang lain. Hakim-hakim yang diangkat Tuhan berikutnya adalah Tola, Yair. Setelah ditindas oleh bangsa Amon, bangsa Israel mempunyai Hakimhakim yang diangkat oleh Tuhan di masing-masing daerah. Hakim-hakim tersebut di antaranya adalah Yefta di daerah Gilead, Ebzan di tanah Yehuda,
Elon di tanah Zebulon dan Abdon di tanah Efraim.

Setelah masa Abdon, bangsa Israel kembali melakukan yang jahat di mata Tuhan, yang mengakibatkan bangsa Israel hidup di bawah penindasan bangsa Filistin. Di dalam masa penindasan bangsa Filistin ini, Tuhan kembali mengangkat seorang hakim penyelamat bangsa Israel yang bernama Simson.

Demikianlah di jaman Hakimhakim, tidak raja di antara orang Israel dan setiap orang berbuat apa yang benar sesuai kemauan mereka sendiri. Di akhir jaman Hakim-hakim ini Tuhan memberikan seorang pemimpin bagi mereka yang akan mempersiapkan bangsa Israel untuk memasuki jaman kerajaan yang akan datang.

\section{Kitab 1 Samuel}

Penindasan orang Filistin kepada bangsa Israel merupakan zaman penindasan paling berat yang dialami oleh bangsa Israel (Prabowo, 2020a, p. 38). Di masa inilah Samuel lahir. Saat Samuel lahir, Imam Eli lah yang menjadi imam besar di Silo (Douglas, 2011a, p. 275). Imam Eli menjadi imam bersama kedua anaknya yang bernama Hofni dan Pinehas. Imam Eli merupakan seorang pemimpin yang tidak tegas dan tidak kuat. Saat anakanaknya, yaitu Hofni dan Pinehas, melakukan kesalahan, Imam Eli memang 
menegur mereka, tetapi tidak menghukum mereka. Hal tersebut membuat Hofni dan Pinehas semakin hari semakin merasa bebas dan menjadi semakin jahat di dalam melakukan tugas keimaman mereka.

Elkana, ayah dari Samuel adalah seorang dari suku Lewi. Elkana mempunyai dua istri, yaitu Hana dan Penina. Hana mandul dan Penina tidak. Sehingga setiap saat Elkana bersama mereka datang ke Silo untuk mempersembahkan korban kepada Tuhan, Penina selalu mengolok-olok Hana karena Hana tidak bisa memberikan keturunan kepada Elkana. Di dalam suatu hari saat Imam Eli melakukan tugas keimamannya di Bait Suci di Silo, Hana, istri Elkana, berdoa kepada Tuhan untuk meminta seorang anak kepada Tuhan. Hana berdoa meminta anak kepada Tuhan karena Hana sangat menderita mendapat perlakuan yang buruk dari Penina karena kemandulannya. Hana bukan hanya berdoa, tetapi Hana juga mengucapkan janji kepada Tuhan. Hana berjanji kepada Tuhan bahwa anak yang akan dia dapatkan dari Tuhan akan dipersembahkan kembal kepada Tuhan untuk menjadi pelayan Tuhan.

$$
\text { Sebagai seorang imam, Eli }
$$
melakukan sebuah pelayanan doa berkat, yaitu doa yang akan mengabulkan permohonan dari Hana. Lalu saat Hana pulang ke rumah, Elkana menghampirinya. Tuhan mengabulkan doa permohonan Hana, Hana mengandung. Hingga akhirnya Hana melahirkan anak yang dikandungnya tersebut yang dinamainya Samuel; yang artinya diminta dari Tuhan dan didengarkan-Nya.

Dengan bukti bahwa Elkana tiaptiap tahun pergi ke Silo untuk mempersembahkan korban dan juga mengikuti perjamuan korban disana, maka di saat itu kedudukan Imam Eli diakui sebagai pemimpin bangsa Israel. Bukan hanya imam Eli yang diakui sebagai imam, tetapi juga anak-anaknya, yaitu Hofni dan Pinehas juga mendapatkan pengakuan yang sama. Menjadi seorang pemimpin bagi bangsa Israel. Bukan hanya seorang pemimpin biasa, tetapi juga seorang nabi yang menyampaikan suara Tuhan untuk orang Israel.

\section{Survey Kitab 1 Samuel}

\section{Konteks Dekat 1 Samuel 2:11}

1 Samuel 2:11 terdapat di dalam Kitab 1 Samuel yang merupakan awal dari Kitab 1 dan 2 Samuel. Kitab 1 dan 2 Samuel merupakan kitab yang menulis perjalanan kepemimpinan bangsa Israel yang berubah dari era Teokrasimenuju kepada kepemimpinan monarki. Kepemimpinan yang awalnya langsung di bawah pimpinan Tuhan menjadi kepemimpinan yang dikuasai oleh seorang 
raja. Sejarah bangsa Isarel digambarkan di dalam Kitab 1 dan 2 Samuel bersama Kitab 1 Raja-raja pasal 1-11 memperlihatkan bahwa pada waktu itu bangsa Israel mengalami perubahan besar di dalam kehidupan mereka. Perubahan yang terjadi di antaranya di dalam kehidupan politik, sosial dan juga keagamaannya (LaSor et al., 2016, p. $325)$.

1 Samuel pasal satu hingga pasal tiga yang merupakan tulisan tentang imam Eli dan Samuel menjadi bagian dari 1 Samuel 1-7 yang merupakan tulisantulisan yang menceritakan tahun-tahun pertama keberadaan dan pelayanan Samuel. Tahun-tahun pertama dari seorang Samuel yang akan menjadi Hakim yang terakhir bagi bangsa Israel dan juga seseorang yang membimbing bangsa Israel di dalam pembentukan pemerintahan kerajaan bagi bangsa Israel. Sebuah penggambaran bentuk pelayanan dari Samuel di tengah-tengah himpitan penindasan dari bangsa Filistin. Bahkan bangsa Filistin juga menyebabkan Silo hancur dan hilang. Bangsa Filistin juga berhasil merebut dan membawa Tabut Tuhan untuk kemudian ditempatkan di Kiryat-Yearim (Vriezen, 2015, p. 77).

Secara khusus di dalam Kitab 1 Samuel pasal 1-3 adalah tulisan-tulisan yang menceritakan masa-masa kecil kehidupan Samuel. Di dalam Kitab 1
Samuel 1-3 ini dibagi menjadi bagian yang lebih kecil lagi. Ada tiga bagian yang ada di dalam Kitab 1 Samuel 1-3 ini (LaSor et al., 2016, pp. 328-333), yang pertama adalah 1 Samuel 1:1-2:11 yang menceritakan kehidupan Hana, ibu Samuel, yang mempunyai kesalehan di dalam kehidupannya. Yang kedua, adalah 1 Samuel 2:12-36 yang menuliskan tentang kehidupan dari penerus Imam Eli, yaitu anak-anaknya Imam Eli yang bernama Hofni dan Pinehas. Dituliskan di dalam bagian ini Hofni dan Pinehas mempunyai kehidupan yang jahat.Bagian yang ketiga adalah panggilan untuk Samuel melayani ditulis di dalam 1 Samuel 3:1-21. Untuk memahami apa yang terjadi di dalam 1 Samuel 2:11 perlu dipelajari bagian-bagian tersebut dengan lebih dalam.

\section{Bagian Pertama}

Secara khusus 1 Samuel 2:11 berada di dalam bagian pertama dari 1 Samuel pasal 1-3 ini. Bagian pertama yang menceritakan kehidupan Hana, ibu dari Samuel yang mempunyai kehidupan yang saleh. Masa kehidupan saat itu adalah bangsa Israel di bawah tekanan dan penindasan bangsa Filistin. Bangsa Filistin adalah salah satu di antara musuh-musuh bangsa Israel yang paling berbahaya dan merupakan ancaman serius bagi bangsa Israel (Hinson, 2019, p. 110). 
1 Samuel dibuka dengan penjelasan dari silsilah ayah dari Samuel. Elkana adalah seorang Efraim yang merupakan keturunan Lewi, 1 Tawarikh 6:34. Elkana mempunyai dua istri. Istri yang pertama adalah Hana dan yang kedua adalah Penina. Hana mandul dan tidak bisa mempunyai anak, sedangkan Penina mempunyai beberapa anak (Paterson, 2017, p. 13). Di dalam kehidupan keagamaannya, Elkana setiap tahun pergi meninggalkan rumah tempat tinggalnya untuk pergi ke Silo bersama keluarganya. Elkana pergi ke Silo untuk menyembah Tuhan dan mempersembahkan korban kepada Tuhan. Di Silo inilah di simpan Tabut Perjanjian (Vriezen, 2015, p. 77) di bawah pimpinan Imam Eli dan juga anakanak nya, yaitu Hofni dan Pinehas.

Pinena selalu menyakiti hati Hana dengan selalu mempermasalahkan kemandulan Hana. Peristiwa ini terjadi berulang-ulang tiap tahun. Hingga di hari itu, Elkana mengetahui bahwa Hana sedih dan tidak mau makan. Sedemikian sedihnya Hana, sehingga Hana menangis di saat berdoa kepada Tuhan. Dalam doanya, Hana mengucapkan nazar bila Tuhan memberikan kepadanya seorang anak laki-laki, maka Hana akan memberikan anak tersebut kepada Tuhan kembali. Nazar adalah sebuah hal yang biasa dilakukan oleh orang Israel manakala menghadapi sebuah kesusahan (LaSor et al., 2016, p. 329).

Sedemikian dalamnya Hana berdoa hingga Imam Eli yang mengawasi Hana mengira bahwa Hana mabuk anggur. Setelah mendengar penjelasan Hana tentang isi doanya kepada Tuhan, Imam Eli memberikan doa berkat kepada Hana. Doa berkat yang diberikan Imam Eli mengamini bahwa Tuhan telah mendengar doa permohonan Hana.Lalu Hana kembali ke rumah bersama Elkana. Satu tahun setelah Hana berdoa Tuhan memberikan apa yang Hana minta. Hana mengandung dan kemudian melahirkan Samuel.

Hal yang perlu diperhatikan adalah Hana tidak serta merta menepati janjinya kepada Tuhan dengan langsung memberikan Samuel kepada Tuhan sesaat setelah Samuel lahir. Hana melewatkan sebuah kesempatan untuk datang ke Silo untuk membuktikan janjinya kepada Tuhan tentang Samuel. Tetapi Hana malah merawat Samuel dengan baik. Salah satu tanda bahwa Hana merawat Samuel dengan baik adalah dengan tetap menyusuinya.

Setelah Samuel disapih dari susu ibunya, Hana mengantarkan Samuel ke Silo untuk diberikan kepada Tuhan. Di dalam 1 Samuel 1:24 disebutkan bahwa Samuel masih kecil betul saat dibawa oleh Hana ke Silo. Banyak ahli berpendapat bahwa Samuel saat itu baru berusia tiga 
tahun. Sesaat setelah Elkana dan keluarganya memberikan korban persembahan kepada Tuhan, Samuel diantarkan ke hadapan Imam Eli. Hana berkata sendiri kepada Imam Eli bahwa Samuel diserahkan kepada Tuhan melalui Imam Eli (Day, 2012, p. 129).

Setelah Hana memberikan Samuel kepada Tuhan, Hana pun bersuka ria memuji Tuhan. Sebuah puji-pujian yang melukiskan betapa besar kemenangan yang Hana dapatkan atas Penina. Sebuah kemenangan atas setiap orang yang mencemoohnya karena kemandulannya.

\section{Bagian Kedua}

Bagian kedua dari 1 Samuel 1-3 adalah 1 Samuel. 2:12-36. Didalam bagian kedua ini digambarkan dengan jelas kehidupan dari anak-anak Imam Eli, yaitu Hofni dan Pinehas. Di dalam bagian kedua ini, penulis berpendapat bahwa di bagian inilah sebuah penjelasan tentang pembanding kehidupan antara Samuel dan kehidupan dari para yang seharusnya penerus kepemimpinan dari Imam Eli.

Kehidupan bangsa Israel yang bercampur dengan bangsa Kanaan mengakibatkan kerusakan di dalam norma atau peraturan-peraturan yang ada di dalam bangsa Israel. Secara jelas dituliskan kerusakan ini terjadi di dalam kehidupan Hofni dan Pinehas. Hofni dan Pinehas melakukan perbuatan yang melanggar peraturan kehidupannya sebagai imam. Di dalam ayat 13-17 terlihat jelas bahwa Hofni dan Pinehas melakukan kesalahan di dalam batas-batas hak mereka sebagai imam di dalam menerima kurban persembahan. Mereka malah meminta bagian dari kurban persembahan dari orang Israel sebelum kurban tersebut dipersembahkan.

Bukan hanya tentang bagian imam di dalam kurban persembahan yang mereka langgar peraturannya. Hofni dan Pinehas juga melakukan perzinahan dengan para pelayan-pelayan wanita di tempat dimana mereka melayani sebagai imam. Apapun motivasi mereka melakukan perzinahan itu, tetap saja perzinahan itu sangat buruk bagi orangorang Israel. Sedemikian buruknya sampai orang-orang Israel melaporkan hal tersebut kepada Imam Eli.

Setelah mendapatkan laporan tentang perbuatan anak-anaknya, Imam Eli memberikan peringatan kepada anakanaknya tersebut. Akan tetapi karena peringatan yang diberikan sangat lemah sehingga membuat Hofni dan Pinehas dengan gampang tidak menuruti peringatan tersebut. Hofni dan Pinehas tetap melakukan perbuatan-perbuatan buruk tersebut. Hofni dan Pinehas tidak pantas untuk melayani Tuhan karena mereka melakukan pelayanan dengan motivasi untuk kepentingan diri sendiri, 
dan mereka tidak hormat akan kekudusan Tuhan dengan mencemari Bait Suci dengan dosa-dosa mereka (Prabowo, 2020b, pp. 128-141).

Bagian kedua dari 1 Samuel 1-3 ini ditutup dengan ayat 26 yang merupakan pembanding bertolak belakang dengan apa yang dilakukan oleh Hofni dan Pinehas. Sebuah perbandingan yang mendukung panggilan Samuel dan juga data pendukung tentang kelayakan dari seorang Samuel sebagai penerus kepemimpinan dari Imam Eli.

\section{Bagian Ketiga}

Setelah bagian kedua memberikan penjelasan tentang keburukan dari para generasi penerus kepemimpinan dari Imam Eli, maka bagian ketiga ini menuliskan tentang panggilan yang diterima oleh Samuel. Panggilan yang Samuel terima adalah sebagai seorang imam dan nabi bagi bangsa Israel, sebagai generasi penerus dari Imam Eli.

Setelah tahapan pertama yang dilakukan oleh orang tua Samuel yaitu tahapan menyerahkan Samuel kepada Tuhan. Samuel mengalami tahapan kedua di dalam kehidupan pelayanannya, yaitu panggilan Tuhan secara khusus diberikan kepadanya. Dari penggenapan janji Hana kepada Tuhan semua proses regenerasi kepemimpinan yang akan dialami oleh Samuel dimulai. Bukti bahwa Tuhan sendiri yang memanggil Samuel adalah penegasan bahwa pengalaman profetik yang dialami Samuel adalah sebuah pengalaman yang menjadikan Samuel sebagai pribadi yang baru. Kesaksian dari orang-orang Israel yang mengetahui tentang perkembangan kehidupan Samuel yang disertai Tuhan membuat proses panggilan Samuel sebagai imam dan nabi menjadi lebih jelas.

\section{Konteks Jauh 1 Samuel 1-2}

Kitab 1 Samuel 1-2 adalah salah satu bagian dari kitab-kitab yang menggambarkan perubahan kepemimpinan dari bangsa Israel. Kitab Hakim-hakim, 1 dan 2 Samuel serta 1 dan 2 Raja-raja menuliskan perjalanan perubahan sistem Teokrasi kepada sistem monarki. Dari kepemimpinan yang langsung dari Tuhan menuju kepada pemerintahan yang dipimpin oleh seorang manusia. Dari kepemimpinan Tuhan melalui Musa, dilanjutkan oleh Harun dan Yosua. Kemudian dilanjutkan dengan dipanggilnya para hakim-hakim untuk memimpin bangsa Israel oleh Tuhan.

Di dalam 1 dan 2 Samuel juga terjadi beberapa proses peralihan kepemimpinan. Dimulai dari kepemimpinan Imam Eli yang diteruskan oleh Samuel. Suatu pergantian kepemimpinan yang di luar adat kebiasaan di masa itu. Jabatan imam yang 
seharusnya diteruskan kepada garis keturunannya, tetapi pada masa selesainya kepemimpinan Imam Eli diteruskan oleh orang yang bukan keturunan dari Imam Eli.

Dilanjutkan dengan peralihan kepemimpinan dari Samuel kepada Saul. Peralihan sebuah kepemimpinan dari yang dipilih Tuhan, yaitu Samuel, kepada yang dipilih oleh bangsa Israel sendiri, yaitu Saul. Perubahan struktur kepemimpinan dari seorang imam kepada seorang raja. Perubahan yang memberikan dampak luar biasa dari berbagai bidang kepada bangsa Israel.

Hanya karena kasih Tuhan kepada bangsa Israel saja yang menyebabkan terjadinya peralihan kepemimpinan yang selanjutnya. Peralihan kepemimpinan dari Saul kepada Daud. Seorang raja yang dipilih Tuhan secara langsung, seperti saat Tuhan memilih para imam, para hakimhakim dan para nabi-nabi untuk memimpin bangsa Israel.

Di masa awal kehidupan Israel sebagai bangsa, seorang pemimpin sangatlah berperan di dalam mengatur kehidupan bangsa Israel. Para pemimpin bukan hanya berperan sebagai pengatur tetapi juga mempunyai fungsi sebagai penyampai pesan Tuhan kepada bangsa Israel.
Pemimpin: Imam, Nabi, Hakim

Di dalam 1 dan 2 Samuel, sosok seorang pemimpin menjadi hal yang utama untuk dibicarakan. Seorang pemimpin yang secara langsung dipilih dan dipanggil oleh Tuhan untuk melakukan kehendak-Nya. Bukan hanya dipilih dan dipanggil oleh Tuhan, tetapi di dalam kehidupannya sebagai pemimpin, orang yang dipilih Tuhan tersebut harus tetap taat dan setia kepada Tuhan supaya kepemimpinannya tetap ada.

Penggambaran tentang pemimpin yang tidak taat dan setia kepada Tuhan terlihat jelas di dalam kehidupan Eli, Hofni dan Pinehas (Zuck, 2015, p. 223). Seorang pemimpin yang secara tragis diakhiri kepemimpinannya oleh Tuhan karena ketidakmampuannya untuk tetap taat dan setia kepada Tuhan. Penggambaran pemimpin yang taat dan setia kepada Tuhan ada di dalam kehidupan Samuel.

Tetapi, dalam kehidupan Samuel dan Daud, peran orang tua sangat berpengaruh di dalam awal proses persiapan Samuel dan Daud menjadi seorang pemimpin. Secara khusus di dalam kehidupan Elkana dan Hana menjadi modal yang baik untuk mempersiapkan Samuel sebagai generasi penerus kepemimpinan bagi bangsa Israel. Ketaatan Elkana dan Hana kepada Tuhan 
menjadi sebuah tahapan penting di dalam awal kehidupan Samuel.

Dari ketaatan orang tua kepada Tuhan, Samuel disiapkan Tuhan untuk menerima panggilan dan tugas ilahi. Sebuah tugas yang berat sebagai seorang pemimpin bagi bangsa Israel. Karena sejak awal Musa dipilih Tuhan sebagai pemimpin bangsa Israel, tugas seorang pemimpin adalah menjadi Imam, Nabi dan Hakim. Sebuah tugas yang dilanjutkan secara turun temurun hingga masa kepemimpinan Imam Eli. Tugas ini juga yang akan diemban oleh Samuel saat menggantikan kepemimpinan Imam Eli. Samuel akan menjadi seorang hakim dan juga sekaligus nabi bagi bangsa Israel (Barth \& Barth-Frommel, 2017, p. 61).

Penyebutan kata "imam" bagi Eli di dalam Alkitab merupakan penyebutan sebuah jabatan, tetapi tidak mencerminkan sebagai tugas. Sebab tugas Eli bukan hanya sebagai Imam bagi bangsa Israel. Eli juga bertugas sebagai nabi dan juga sebagai hakim bagi bangsa Israel (Bakker, 1993, p. 459). Kalaupun Samuel akan menjadi penerus kepemimpina dari Imam Eli, maka Samuel pun juga harus bisa menjadi seorang imam, nabi dan juga hakim bagi bangsa Israel. Sebuah hal yang mungkin tidak ada di dalam benak dan di dalam rencana Hana saat Hana menyerahkan Samuel kepada Tuhan di masa kanak-kanak Samuel. Hana hanya sekadar menepati janjinya kepada Tuhan dan menyerahkan kehidupan Samuel selanjutnya kepada Tuhan.

\section{Pembahasan}

1 Samuel 2:11 Lalu pulanglah Elkana ke Rama tetapi anak itu menjadi pelayan TUHAN di bawah pengawasan imam Eli (BibleWorks 7, n.d.-a, p. 1 Samuel 2:11).

1 Samuel 2:11 di dalam versi Indonesia Terjemahan Baru diawali kata “Lalu pulanglah" (Indonesia, 2005, p. 1 Samuel 2:11). Yang dari bahasa aslinya adalah kata kerja \%l,YEôw :dari kata dasar \%l;h '(h'lak) (BibleWorks 7, n.d.-b, p. 1 Samuel 2:11) yang di dalam bentuk qal mempunyai arti berjalan atau pergi, dan di dalam bentuk imperfect mempunyai arti sebuah tindakan yang belum selesai dilakukan. Sehingga bisa diartikan saat itu Elkana baru saja mulai berjalan pulang ke Rama.

Kata "Lalu pulanglah" di dalam 1 Samuel 2:11 ini mempunyai peran yang penting di dalam keseluruhan awal kehidupan Samuel sebagai pelayan Tuhan. Elkana yang setahun sekali datang ke Silo untuk memberikan kurban persembahan kepada Tuhan, saat itu tetap pulang ke Rama dengan meninggalkan Samuel di Silo. Elkana dan keluarganya, termasuk Hana, meninggalkan Samuel yang 
kemungkinan masih berusia tiga tahun di Silo (Douglas, 2011b, p. 354). Samuel ditinggalkan di Silo sesuai dengan janji Hana kepada Tuhan untuk menyerahkan Samuel kepada Tuhan.

Sebagai seorang ibu, Hana menyiapkan Samuel dengan baik dengan merawatnya dan memberinya air susu. Bukan hanya memberi air susu, tetapi Hana juga mendidik Samuel dan mempersiapkannya untuk Tuhan (White, 1977, p. 172). Elkana sebagai seorang ayah juga mempunyai hati yang kuat untuk meninggalkan anak sulungnya dari Hana untuk menjadi pelayan Tuhan di Silo. Pulangnya Elkana ke Rama membuktikan bahwa Elkana juga memberikan restu kepada Hana untuk memberikan Samuel kepada Tuhan.

Kepulangan Elkana ke Rama juga menjadikan proses mulainya Samuel menjadi pelayan Tuhan bisa terlaksana. Elkana bersedia untuk tidak menjadi pengawas pertumbuhan anaknya. Elkana menyerahkan kehidupan Samuel kepada Tuhan, seperti yang Hana lakukan kepada Samuel. Sebuah kesepakatan antara suami-istri yang tetap taat dan setia kepada Tuhan. Elkana dan Hana bersepakat untuk menepati janji Hana kepada Tuhan. Elkana menjadi seorang suami yang percaya kepada istrinya, yaitu Hana, bahwa keputusan Hana untuk menyerahkan Samuel kepada Tuhan adalah hal yang tepat.

Elkana dan Hana mengantar Samuel ke Silo untuk diserahkan kepada Tuhan melalui Imam Eli. Kedua orang tua Samuel ini meyakinkan diri mereka sendiri bahwa realisasi dari apa yang menjadi janji mereka berada di jalan yang tepat. Elkana dan Hana menyerahkan Samuel kepada Imam Eli. Imam Eli pun menerima Samuel untuk belajar menjadi pelayan Tuhan di bawah pengawasannya. Tidak ada sebuah janji atau pengharapan yang diberikan Imam Eli (atau Tuhan) kepada Elkana dan Hana bahwa suatu saat nanti Samuel akan menjadi seorang pemimpin bagi bangsa Israel. Semua tahapan awal dari kehidupan Samuel sebagai pelayan Tuhan dikerjakan oleh Elkana dan Hana hanya sebagai bukti ketaatan dan kesetiaan mereka kepada Tuhan dengan menepati janji yang pernah diucapkan Hana di dalam doanya (White, 1977, p. 173).

Tidak ada peran dari Samuel di dalam tahapan awal ini. Semua peran dalam tahap awal kehidupan Samuel menjadi pelayan Tuhan dilakukan oleh kedua orang tua Samuel dan juga Imam Eli. Elkana dan Hana mempunyai ketaatan dan kesetiaan kepada Tuhan, dengan bukti bahwa mereka setahun sekali memberikan kurban persembahan di Silo. Hana menepati janjinya kepada Tuhan untuk 
memberikan anak yang sangat diharapkannya kepada Tuhan. Elkana mempunyai kepercayaan yang penuh kepada keputusan istrinya untuk memberikan Samuel kepada Tuhan. Elkana percaya kepada Imam Eli untuk bisa merawat Samuel. Elkana juga mempunyai kepercayaan penuh kepada Tuhan bahwa Tuhan akan melakukan hal yang baik kepada Samuel.

Imam Eli pun dengan tangan terbuka menerima Samuel di bawah pengawasannya untuk menjadi pelayan Tuhan. Sebuah hal yang sangat baik dilakukan oleh Imam Eli, karena Imam Eli menerima Samuel di saat berusia kanakkanak. Perlu sebuah usaha dan juga kerja keras untuk merawat seorang kanak-kanak seperti Samuel sehingga bisa menjadi seorang pelayan Tuhan.Imam Eli akan menjadi seorang teladan bagi Samuel di dalam melakukan pelayanannya kepada Tuhan di Silo. Teladan yang Samuel lihat di dalam kepemimpinan Imam Eli adalah hal yang penting bagi Samuel (D’Souza, 2007, p. 2). Hubungan secara pribadi dari orang dewasa yaitu imam Eli kepada anak-anak yaitu Samuel, akan menuntun Samuel untuk membangun dasar bagi pandangannya mengenai dirinya sendiri dan juga tentang dunia pelayanannya (Haystead, 1988, p. 5). Sehingga pada waktunya nanti, Samuel menjadi tokoh istimewa. Samuel menjadi yang terakhir dari hakim-hakim dan yang pertama dari nabi-nabi (Baxter, 2016, p. 203).

\section{Kesimpulan}

Di dalam menyiapkan calon penerus regenerasi kepemimpinan Kristen, peran orang tua sangatlah penting. Di dalam 1 Samuel 2:11 sangat terlihat peran dari seorang ayah yang percaya Tuhan, kepada istri dan juga kepada pemimpin dimana anak ditempatkan menjadi sangat penting.

Jauh mendahului dari peran si calon pemimpin itu sendiri, peran orang tua menjadi sebuah tahapan penting di awal pembentukan seorang pemimpin. Orang tua yang taat dan setia kepada Tuhan. Orang tua yang berharap kepada Tuhan. Orang tua yang menepati janji kepada Tuhan. Orang tua yang merawat anaknya dengan baik. Orang tua yang berserah penuh kepada Tuhan. Sebuah tahap awal yang penting untuk dilakukan untuk menghasilkan para calon pemimpin yang takut akan Tuhan dan mampu menerima panggilan serta melakukan tuagsa kepemimpinan dengan baik. Sebelum Tuhan membentuk si anak menjadi pelayan Tuhan, Tuhan membentuk orang tuanya terlebih dahulu menjadi orang tua yang menyiapkan dan memberi restu kepada anak untuk menjadi pelayan Tuhan. 
Setiap orang Kristen bisa belajar dari sikap Elkana dan Hana di 1 Samuel 2:11 ini. Kepulangannya ke Rama setelah beribadah kepada Tuhan di Silo memberikan makna yang dalam bagi setiap orang tua. Agar seorang anak bisa menjadi pelayan Tuhan dan pemimpin yang baik di masa depan, maka orang tua harus mempersiapkan dan merawat anaknya dengan baik. Selain itu orang tua juga harus memberikan restu kepada sang anak untuk menjadi pelayan Tuhan. Juga para pemimpin dimana tempat anak tersebut belajar melayani harus benarbenar mengawasi setiap detail kehidupan anak tersebut. Bukan hanya mengawasi di dalam kegiatan pelayanan rohani, tetapi juga merawat dalam arti jasmani. Sehingga seorang anak bukan hanya bertumbuh dengan baik dari segi rohani saja, tetapi jasmani juga dalam keadaan bertumbuh dan sehat sehingga seorang anak mampu melakukan pelayanan kepada Tuhan dengan baik di dalam jangka yang panjang.

\section{Daftar Pustaka}

Bakker, F. L. (1993). Sejarah Kerajaan Allah 1. BPK Gunung Mulia.

Barth, D. C., \& Barth-Frommel, M.-C. (2017). Teologi Perjanjian Lama 2. BPK Gunung Mulia.

Baxter, J. S. (2016). Menggali Isi Alkitab 1. Yayasan Komunikasi Bina Kasih. BibleWorks 7. (n.d.-a).
BibleWorks $7 . \quad$ (n.d.-b). WTM Morphology.

D'Souza, D. A. (2007). Proactive Visionary Leadership. Trisewu Nagawarsa.

Day, T. J. (2012). Kisah Tokoh-tokoh Unik dalam Alkitab. Yayasan Kalam Hidup.

Douglas, J. D. (2011a). Ensiklopedi Alkitab Masa Kini Jilid I A-L. Yayasan Komunikasi Bina Kasih.

Douglas, J. D. (2011b). Ensiklopedi Alkitab Masa Kini Jilid II M-Z. Yayasan Komunikasi Bina Kasih.

Hamzah, A. (2020). Metode Penelitian Kepustakaan. Literasi Nusantara.

Haystead, W. (1988). Mengajar Anak Tentang Allah. BPK Gunung Mulia.

Hinson, D. F. (2019). Sejarah Israel pada Zaman Alkitab. BPK Gunung Mulia.

Indonesia, L. A. (2005). Alkitab Terjemahan Baru. Lembaga Alkitab Indonesia.

John C. Maxwell. (1999). The 21 Irrefutable Laws of Leadership: Follow Them and People Will Follow You (electronic). Thomas Nelson Publishers.

LaSor, W. S., Hubbard, D. a., \& Bush, F. W. (2016). Pengantar Perjanjian Lama 1. BPK Gunung Mulia.

MacArthur, J. (2004). The Book on Leadership: The Power of a Godly Influence. T. Nelson Publishers. 
Paterson, R. M. (2017). Tafsir Alkitab

Kontekstual-Oikumenis 1\&2 Samuel.

BPK Gunung Mulia.

Prabowo, W. (2020a). Perjalanan Sejarah

Bait Suci dari Perjanjian Lama, Masa

Intertestamental hingga Masa

Pelayanan Yesus. Jurnal Teologi

Berita Hidup, 3(1), 33-47.

https://doi.org/10.38189/jtbh.v3i1.46

Prabowo, W. (202n0b). Aplikasi Prinsip

Mazmur 2:11-12 dalam Peribadahan

Kristen. Jurnal Teologi Berita Hidup,

2(2), 128-141.

https://doi.org/10.38189/jtbh.v2i2.34

Vriezen, T. C. (2015). Agama Israel Kuno. BPK Gunung Mulia.

White, E. G. (1977). Para Nabi dan Bapa 2. Indonesia Publishing House.

Zuck, R. B. (2015). A Biblical Theology of the Old Testament. Gandum Mas. 